\title{
Introduction and overview
}

\section{Theoretical framework}

Chapter 1 develops theoretical constructs that will guide the analysis in ensuing chapters. Its central argument is that post-communist convergence between the Visegrád Four (V4) defense policies is best understood as a result of the universal adoption of liberal-democratic political systems and ideologies by the countries in question. However, the chapter argues, post-communist divergence in the respective countries' defense policies, made especially visible by their post-2014 differential reactions to the Russo-Ukrainian Crisis and its fallout, cannot be understood within the framework of liberalism as both a political system and a theory of international relations. Different schools and concepts of realism and constructivism are therefore evoked as necessary for illuminating the noted divergence between Poland, which responded robustly and in militaristic fashion to the perception of a Russian threat, and the rest of the Visegrád countries, with their lukewarm responses. Within realism, the chapter draws attention to Poland's distinctive geopolitical position. Within constructivism, the chapter considers the notions of 'role theory' and 'strategic cultures' as a key for understanding the countries' diverging polices.

\section{Pre-1945 historical and political experiences}

Chapter 2 focuses on the deep regional and historical contexts that were characteristic of the period leading up to the imposition of communist controls in the late 1940s. There is differentiation between the long era leading up to nation-state formation after the First World War and the interwar/Second World War era.

Prior to 1918 , there was much historical variation in the political experiences of the four geographic units spread across the East-Central European region.

Czechs fell under Austrian control after their defeat at the Battle of 
White Mountain in 1620, and so three centuries under the control of Vienna became their destiny but also the source of deep resentment against control by an outside power. However, Bohemian experiences prior to the defeat by Austria became a kind of basis for national pride and even democratic expression in later decades. The memory of King Wenceslaus in the tenth century animated artists and musical composers in the late nineteenth century. Contributions of King Charles IV in the fourteenth century reminded later Czechs of the importance of his reign as well as practical results such as the creation of the second oldest university in Europe, construction of the famous bridge across the Vltava River, and initial work on what later became known as Prague Castle. A century later, Jan Hus inspired a movement that challenged domination from Rome and the detailed strictures of the Catholic Church. As such, the Hussite battles animated later aspirations for popular participation within the Austrian Empire and beyond.

For Poles, the key memory was loss of their geographic, territorial, and political homeland, which had been a large multinational empire, between the partitions by the three large empires in the 1790s and recreation of their own state after the First World War. Just like in the Czech case, the memories of pre-foreign colonization glories animated Polish nationalism of the nineteenth century. Indeed, early nineteenthcentury dreams of its recreation led Romantic poets such as Mickiewicz to compare Poland's situation to that of the crucified Christ. According to Mickiewicz, Poland's intense religiosity and loyalty to Rome would somehow bring about a national resurrection, which in turn would usher in a universal liberation of all peoples of Europe. In more concrete terms, Poles continued their military and political struggles for independence under Napoleon and in a series of national uprisings (1830, 1846, 1848, 1863, 1905), mostly aimed against Russia. It was also in a war against Soviet Russia that Poland solidified its independence in the 1918-20 period.

In contrast, Budapest was in charge of a large empire that included Romanians, Serbs, Ukrainians, Slovaks, and others. It shared center stage with the more powerful Austrian Empire to the northeast, but still its leaders had plenty of room for self-confidence, in contrast to the Poles and Czechs. Merging of the two Central European Empires into the Dual Monarchy in 1867 provided a location and status for Hungary that the envious Czechs never received.

The Slovak situation was quite different, in part because of its smaller size in comparison to the other three units that eventually became nations in the Visegrád Group. Lack of attention from Budapest left the Slovaks in need of much development after becoming part of Czechoslovakia 
in 1918. It may be that their intense Catholic religiosity was also a substitute for the lack of political clout. Joining with the more developed Austrian-dominated Bohemia after the First World War may have led to a sense of dissonance, as the Czechs clearly dominated the newly created Czechoslovakia, and many Slovaks felt that they substituted one form of subordination for another.

Between 1918 and 1945, transitions were more similar in the region under consideration. All developed democratic political forms to fit into their new nation-states under heavy pressure from the West after the end of the Great War. After all, President Woodrow Wilson had taken the US into the war to make the world safe for democracy. However, by the end of the 1920s, only Czechoslovakia retained those democratic forms in the manner in which they had been created. Hungary's six-month experiment with communist rule in 1919 led to a military crackdown, while Marshall Piłsudski had risen to power in Poland by the late 1920s. The emergent authoritarian patterns of the late 1920s and early 1930s multiplied and morphed into profoundly different totalitarian rule once Hitler's conquests commenced in the mid-to-late 1930s. Concentrated rule from Berlin was the sharpest possible contrast to the quiet democratic hopes of 1918. Rule by outside invaders, establishment of concentration camps, and efforts to eradicate the large Jewish population in the region stimulated common fears and enormous tragedies within the whole of Central Europe.

The legacies from this long historical period for the region after 1989 are many and, as to be expected, point to divergence among the four. A legacy of democratic expression may be most characteristic of the Czechs. The Hussite revolts against control by Rome in the fifteenth century, political and cultural expressions of resistance to Vienna in the late nineteenth century, and a relatively successful experiment with democracy in the 1920s, put a stamp on their activities after the fall of communism. In contrast, Slovak legacies centered on smoking resentment at their subordination to outside powers with little chance for their own national autonomy. First Budapest and then Prague after 1918 became authority symbols that seemed to demonstrate continuing insensitivity to Slovak needs and distinctiveness. Thus, it is not too surprising that they created their own nation-state in 1993, merely four years after the overthrow of the Czech-dominated communist system. For Poles, a resistant and undying devotion to their territorial state and the looming Russian threat was a lesson from past history, and so it is understandable why their leaders after 1989 sought to play a critical and central role in the narrowly defined region, as well as within the wider framework of EU and NATO. Hungary had become used to a larger 
state and the dominant role within it in the period prior to 1918. The Treaty of Trianon sharply cut back on its size and provoked a strong nationalist reaction. A legacy that carried over into post-communist times was an intense desire to protect those Hungarians who ended up outside the nation. Under Prime Minister Viktor Orbán after 2010, this kind of self-defensiveness and protectiveness appeared to many observers to be extreme and part of the ultra-nationalist European movements that took out their frustrations on migrant groups that had ended up in their nation. Hungary's negative reaction to the huge inflow of migrants from Syria and elsewhere in September 2015 was a powerful expression of this outburst of extreme nationalism.

The theme of political development also looms large in considering the preparedness for effective self-rule within a democratic political framework after 1989. In so many ways, the historical and political transitions converged. Certainly, the experience of each of the newly freed states after 1989 had been with state-centered varieties of political development. Subordination to imperial rule was a common pre-1918 political pattern for all four post-communist states, and was also the dominant reality of the 1945-89 period. Even though the imperial controls had been characteristic of the distant past, historical memories of them continued to percolate throughout the cultures. German and Soviet occupations again took away any traditions of self-rule and democracy that had germinated in the 1920s, as subordination to a massive, centralized, terroristic state became the hallmark for nearly a decade.

The democratic components of political development were not exactly out of sight but were harder to delineate as important features of their national experiences. Each of the three post-First World War EastCentral European states set up democratic (or, semi-democratic, in the Hungarian case) systems under considerable Western pressure. Their situation paralleled that of the defeated German state with its Weimar Republic. However, in all of these European cases (with the partial exception of Czechoslovakia), the participant political culture that must underpin democratic institutions and governance was shaky. They had all been in the habit of following political directions from the imperial capitals, and so the fuel that would power the practice of democracy was at a very low level.

\section{The communist era, 1945-89}

Chapter 3 centers on the important key points that may have figured in security policy formation after 1989. Interestingly, each of the three nations in communist times revolted against the combined force of 
their own local communist regimes and Moscow. In 1956, Poland challenged the presence of Soviet personnel in their own political system and emerged with limited autonomy after successfully defying and pacifying the Soviets, after Khrushchev flew the Politburo into Poland in a show of force. During the same year, the Hungarians developed a broad based program of reform under Nagy that anticipated a multiparty political system as well as the growth of representative interest groups. Departure from the newly created Warsaw Treaty Organization (WTO) was also part of the program. Invasion by the troops of the Soviet military brought a quick halt to the reforms and led to an outflow of refugees. The Prague Spring Reforms of 1968 in Czechoslovakia were equally broad based but also included a significant demand for greater protection of freedom of expression. Invasion by Warsaw Pact forces in August of the reform year replaced the Spring with a deadening Winter. The Polish challenge continued to resonate in future decades, with significant demands expressed in 1970, 1976, and 1980. The Solidarity challenge of 1980-81 was rooted in considerable popular support and spread like wild fire throughout the nation. Surprisingly, a crackdown by the Polish military, rather than outside forces, brought it to an end. Significantly, only Poland avoided Soviet invasion, which, the book claims, is an important part of explaining post-1989 long-term divergence between Poland and the other Visegrád countries.

However, the larger picture in all three East-Central European nations was the uniformity of rule by communist elites through institutions inherited from the Soviet model. National leaders emerged through the mystery of inside politics within the respective Politburos, and policy ratification occurred through the Central Committee sessions that regularly occurred throughout the year. Every five years, Party Congresses took center stage, with accompanying newspaper issues often printed in the characteristic "red." Recentralization of controls in Moscow was the normal pattern after the repression of the local reform movements, and the rebellions seemed to be the exception rather than the rule.

All of the above-described events and patterns have national security implications and thereby influenced defense thinking and paradigms after 1989. In terms of actual legacies, the three nations in communist times each challenged Soviet controls in somewhat different ways. Thus, the lessons that they extracted from each episode would probably have been different, and so divergence of conclusions may have been likely. In addition, each of them had been part of the Warsaw Pact but also victims of it. That experience may have carried over after 1989 in terms of their differing expectations about becoming part of Western security organizations such as NATO and EU. They joined the Western alliance 
voluntarily, but still they may have inherited a kind of ambivalence about following dutifully each proposal and project that came from Brussels.

In terms of political development, the lack of attention in communist times to anything connected with democracy may have produced convergence of experiences and expectations for all of the Visegrád players. Now, after a quarter of a century of democratic practices in the four countries, it is clear that it takes a long time to develop the strong roots of a stable democracy in a short period of time. Political parties have come and gone, while national leaders have risen to power quickly but have fallen from grace just as fast due to inexperience, corruption, or the tendency to become wrapped up in causes that have no staying power. In spite of that reality, democratic development has proceeded apace, and it may be that the apparent shallowness of the political roots of democracy is related to the common and converging experience of wanting never to repeat the excessively statist solutions of the communist era.

\section{Country studies}

Each of the four nations will receive attention in a separate chapter dealing with the high points of national defense and security policy considerations after 1989. Some experiences are held in common. For example, each of the Visegrád nations joined NATO in the 1999-2004 period. Each contributed troops and experienced casualties through participation in alliance projects. Their military involvement in Bosnia after the 1995 Dayton Agreement and in Kosovo after NATO engagement in 1999 made sense in terms of overall alliance goals. Part of the reason for offering membership to East-Central European nations was to have full-fledged regional partners who could contribute to nearby areas of conflict. For Hungary, especially, pacification of the Western Balkans contributed directly to the country's security. The Visegrád countries' contribution to the American-led operations in Afghanistan and Iraq, likewise, revealed the countries' common desire to show loyalty to NATO and its hegemon.

However, dramatically different rates at which the countries contributed to multilateral operations also showcased the growing divergence in their respective defense policies and capacities. As our analysis shows, Poland stood out in its continuous emphasis on military capacity and, therefore, in the desire and ability to contribute to multilateral missions. This was a result of a combincation of internal and external factors, the former conditioned by the country's political culture, and the latter by the perception and reality of Russian threat. Conversely, the other 
V4 countries had cultures which de-emphasized military spending, and developed threat perceptions in which Russia did not feature in any prominent way. Reasons for this divergence are given below.

\section{Return to the theoretical framework}

Chapter 8 pulls together the emergent data from the four country security studies in light of the initial theoretical components. What legacies from the pre-1989 period gave each of their security policies such a distinctive flavor and contributed to divergence within the Visegrád defense community? How did their own political development after 1989 generate convergence among them on questions of national security? In answering these questions, the book contributes to the building of theory on the matter of East-Central European security questions. In light of the Ukrainian/Crimean Crisis and resurgent Russian policy ambitions, these are questions of considerable importance. 